\title{
Nyadar: Religious and Cultural Resistance of Madurese Salt Farming Community
}

\section{Nyadar: Religiusitas dan Perlawanan Kultural Masyarakat Pegaraman Madura}

\author{
Iskandar Dzulkarnain ${ }^{1, *}$, Endriatmo Soetarto, Rilus A Kinseng, Sofyan Sjaf \\ ${ }^{1}$ Department of Communication and Community Development Sciences, IPB University, Bogor 16680, Indonesia \\ ${ }^{*}$ Corresponding author: iskandar.dzulkarnain@trunojoyo.ac.id
}

\begin{abstract}
This article discusses the issues of religious and cultural resistance of Madurese salt farming communities as portrayed in the religious tradition of nyadar ritual. Nyadar is an annual religious tradition carried out by Madurese salt farming communities in Sumenep district, precisely in Pinggir Papas Village, Kalianget District and Gersik Putih Village, Gapura District, to conduct cultural resistance against the hegemony and dominance of the Salt Farming Corporation and Madurese salt farming community elites. The purpose of this study is to reveal changes in the cultural situation of the Madurese salt farming community. This study uses an ethnographic method with a constructivist paradigm with data collection methods using in-depth interviews, participant observation, and focus group discussions (FGD). The result of this research found that nyadar is a form of religious rituals that illustrates the solidarity of the community in fighting against the shackles of poverty and helplessness to fight the hegemony and domination of the economic liberalism capitalism in the globalization of the global salt economy which tends to favor the salt corporation, the owners of salt farm land, the religious figures, and the Madurese elites. The cultural resistance of the salt farming community is portrayed in the rejection of the various policies that will be enforced by the Government, PT. Garam, as well as salt corporates in the religious ritual tradition of nyadar including in determining the time of event, religious tourism destinations, and financial support to celebrate the religious ritual activities of nyadar.
\end{abstract}

Keywords: Madura, Nyadar, Resistance, Salt Farming Community, Sumenep.

\section{ABSTRAK}

Artikel ini membahas tentang persoalan religiusitas dan perlawanan kultural masyarakat pegaraman Madura yang terpotret dalam tradisi ritual keagamaan nyadar. Nyadar merupakan sebuah tradisi keagamaan tahunan yang dilakukan oleh masyarakat pegaraman Madura di Kabupaten Sumenep, tepatnya di Desa Pinggir Papas, Kecamatan Kalianget dan Desa Gersik Putih, Kecamatan Gapura, untuk melakukan perlawanan kultural terhadap hegemoni dan dominasi yang dilakukan oleh korporasi pegaraman maupun elit-elit masyarakat pegaraman Madura. Tujuan penelitian ingin mengungkapkan bentuk perlawanan kultural masyarakat pegaraman Madura. Penelitian ini menggunakan metode etnografi berparadigma konstruktivis dengan metode pengumpulan datanya menggunakan wawancara mendalam, obervasi partisipan, dan focus group discussion (FGD). Hasil riset ini peneliti menemukan bahwasanya nyadar sebagai sebuah bentuk ritual keagamaan yang menggambarkan solidaritasan masyarakat pegaraman dalam melawan belenggu kemiskinan dan ketidakberdayaan untuk melawan hegemoni maupun dominasi liberalisme ekonomi kapitalisme dalam globalisasi ekonomi global garam yang cenderung berpihak kepada korporasi garam dan pemilik talangan garam maupun tokoh-tokoh agama dan kalangan elit Madura. Perlawanan kultural masyarakat pegaraman terpotret dalam penolakan terhadap ragam kebijakan yang ingin diberlakukan oleh Pemerintah, PT. Garam, maupun korporat pegaraman dalam tradisi ritual keagamaan nyadar, termasuk penentuan waktu pelaksanaan, destinasi wisata keagamaan, dan bantuan untuk memeriahkan kegiatan ritual keagamaan nyadar.

Kata kunci: Masyarakat Pegaraman, Madura, Nyadar, Perlawanan, Sumenep.

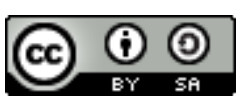

Content from this work may be used under the terms of theCreative Commons Attribution-ShareAlike 4.0 International. Any further distributionof this work must maintain attribution to the author(s) and the title of the work, journal citation and DOI.

Published under Department of Communication and Community Development Science, IPB University and in association with Ikatan Sosiologi Indonesia

E-ISSN: 2302-7525 | P-ISSN: 2302-7157 


\section{INTRODUCTION}

Portraying a cultural resistance of the salt farming community in Madura as a result of the agrarian oldness (gloom) of the salt farming community is something that has never been written, researched, or studied before, although Madura is a region from which the reference of various studies on social resistance is taken.

Talking about social resistance in Madura is not something new; there have been many studies on it. The study of social resistance began during the feudal period (kingdom) and the period of Dutch Colonialism; Trunojoyo was one of the main actors who carried out this resistance during the feudalistic and Dutch colonialism (Kasdi, 2003). The resistance was made by Trunojoyo to the leadership of Amangkurat $\mathrm{I}$ in Mataram Kingdom who collaborated with the Dutch colonialism (Anshory Ch, 2008). This resistance continued when the Mataram Kingdom was led by Amangkurat II, whose government was truly a creation of the Dutch colonialism, led by Cakraningrat IV (Ricklefs, 2005).

The resistance movement continued around the 19th century due to the monopoly on the production and supply of salt, although the pattern of resistance was individual and closed (Dzulkarnain et al., 2020). Then, in the 20th century together with the anti-colonialism movement and the spirit of nationalism, the resistance movement was collective and open. This resistance arose as a result of the clearing of lands by the government. The failure of the salt harvest in 1909 and 1910 resulted in the swelling of the salt farming people's debt, which then led to the rise of a resistance movement through a labor strike and the burning of the salt warehouse (de Jonge, 1991; 2004). The onset of the Madurese community resistant movements later became a national issue when Sarikat Islam (SI) raised the issue of discernment in discussions with the 'Parliament' of the Dutch East Indies (Volksraad) (Kuntowijoyo, 2002). The first session was held on May 21, 1918 with Dr. J. C. Koningenberger as the chair of Parliament for a one-year term (1918-1919). This parliament, as a legislative body, did not have power, except the rights to give advice and petition, namely proposals to solve the problems of indigenous people although the proposal was often rejected by the Governor General of the Netherlands. These problems then triggered the emergence of a resistance group called Radicale Concentratie, which later formed the Indonesian Political Association (GAPI) in 1940 (Herkusumo, n.d.).

In 1934 and 1936 there was another conflict between the government and the salt farming people. The purchase of about one fifth of the community's salt farm land was carried out by the government with a very cheap compensation and without taking sides with the salt farming people. In 1934 the government relocated the salt farming community and in 1936 took over all of the community's salt farm lands. Consequently, several people of the salt farming communities were imprisoned, which led to physical conflicts (Suwondo, 1982).

Then, the resistance of the Madurese community after the Indonesian independence was portrayed in three forms. First, it occurred in the mid-1950s when the government banned the community from producing salt within a $10 \mathrm{~km}$ radius of the salt farming lands owned by the government. The salt monopoly by the Government and nationalization of Dutch companies, in accordance with Law No. 86 of 1958 whose main purpose was to overhaul the colonial economic system into a national economic system, also became a problem which triggered the birth of the resistance of the salt farmers (Kanumoyoso, 2001). Second, the impact of the issuance of the Agrarian Reform Act of 1960 where the owners of salt farm lands who did not originate in the land of salt farm land were forced to release all or part of the salt farm lands to the Indonesian Government at a fixed and very cheap price. Third, the resistance of the salt farming community began in 1975 and has continued until now. This resistance was caused by the modernization project carried out by the Government of Indonesia to expand the lands of PT. Garam with an area of $\pm 1,000$ hectares, or $\pm 1,200$ plots of salt farm land in 17 villages in the area of salt farm lands in Sumenep Regency, which had to be sold to PT. Garam, and this happened for four times within forty years, which affected the community of salt farmers (de Jonge, 2012), and in 2018-2019 there was a number of salt farming lands that had to be freed, including four villages in Gapura District.

The reform period (1998-present) of resistance from Madurese community increasingly becomes strengthened, collectively and openly. In 2010 there were four times resistances against the corporation (PT. Garam) (Rachman, 2011). Nurhajarini (2005) and Fajariyah (2016) revealed the riot 
of salt farm land in Sampang and Yulinda et al., (2014) regarding the conflict in the salt farm land in Sumenep. Then, Rochwulaningsih (2016) stated about the daily resistance of salt farmers. Another social resistance from the salt farming community in Madura was portrayed in disguised resistance (Dzulkarnain et al., 2020). In addition to the various social resistance carried out by the Madurese salt farming community, cultural resistance from the other Madurese salt farming communities also emerged, which was formed in religious rituals.

This resistance has been portrayed in the 'culture' of the salt farming community; the Nyadar tradition. The strong traditional values of animism and dynamism as well as the values of Islam in this culture of awareness is very clear, where Anggasuto as the early inventor of salt was considered as a figure who could free the community from misfortune among the community (Soegianto, 2003). The resistance of the Madurese community was also due to the monopoly since the period of Dutch colonialism (de Jonge, 2012; Parwata, 1997; Parwoto, 2018), including the competition for salt transportation dominated by the corporation (Syafi, 2013).

It turns out that salt as an important commodity will always be contested through the strength of the political economy. Import policy is one form of global economic liberalization in salt, although this policy has an impact on the marginalization of salt farmers (Rochwulaningsih, 2008); (Helmi \& Sasaoka, 2018). The salt import policy by the state as a form of economic liberalization eventually leads to the government's partisanship towards the salt-farming community to strengthen the economy through domestic policies that were for the people but actually failed (Boenarco, 2012.); (T. dan A. A. Kurniawan, 2013), even though the development of indutrialization since the Dutch colonialism has been undergoing de-industrialization (Dick, 1998).

Furthermore, to strengthen the policies that are for the community of salt farmers, and as an effort to maintain a surplus of salt for consumption and salt for industrial purposes, the government implements 'Community Salt Business Development (PUGaR)' (B. A. Kurniawan, 2016), one of whose strategies is to encourage the community to manage businesses with a corporate pattern, which then led to the concept of "corporatization of people's salt" (Baekhaki et al., 2015). According to Soetarto (2007) rural communities in general will never be separated from the structure of local communities in understanding the structure of social stratification based on land ownership. Soetarto, E \& Shohibuddin (2005), said that "control over agrarian sources or objects in addition to being a factor of production is also the basis for the main social structure, and mastery over it will have implications of broader power, both in the physical and social domains".

The diverse resistance of the Madurese community, which is collective and closed, is seen as the cultural resistance that is carried out by the Madurese community in fighting against the powerlessness of corporate and state hegemony and domination of the Madurese community. The religious leaders and local elites were unable to remove the shackles of poverty in the Madurese community; instead, they tend to favor the corporation and the state. This helpless community has been the cause of group solidarity and collective action to fight. This action is a form of resistance from the reaction to the dominance of the lower classes, namely the Madurese community. This resistance is also an act of the salt farming community to survive. According to Scott (1977), resistance in this case is not only sourced from a mere material basis, but also from the dominant ideology as an 'ideological counter' in the socio-cultural space, such as folklore, culture, gossip, humor which is used as a form of expression of resistance and disobedience. This is where the religious tradition of the Madurese community in the form of awareness, comes as a weapon of cultural resistance to the Madurese community, a portrait of a 'weapon of the weak' (Sajogjo, 1993), which becomes the research question in this article.

There have been a lot of researches on the resistance of agrarian societies and fishing communities, one of which was a research done by Wolf (2004), who portrayed the resistance of peasants in six different countries, namely Russia, China, Vietnam, Algeria, and Cuba around the 1900s - 1960s. He noticed that the social resistance of the peasants emerged as an effect of the policies issued by the colonial countries such as commodification, seizing, and impoverishment of the farmers. The goal of the resistance was the struggle over land, rent, taxes, debt, forced planting, forced labor, and labor control. Claims for economic progress and the civilization of white people were the main reasons for the colonialism, by modernizing agriculture as part of the economic development strategy.

Wolf (2004) further explains that resistance in the twentieth century referred to the resistance to ancient feudal regimes that occurred in Russia and China, and against the old regimes of colonial rule, 
such as in Mexico, Vietnam, Algeria, and Cuba (Bernstein, 2015). The resistance that occurred in the six regions was part of the issues of land, rent, taxes, impoverishment, oppression, and social injustice which then triggered the farmers' resistance movements. Farmers' movements are usually part of the national independence movement or social revolution, although such a social resistance movement emphasizes the strategic role of the middle farmers (Bernstein, 2015) and (Landsberger, H. A \& Yu, 1981) about upheaval peasants through the rebellions and revolutions they did.

Meanwhile, peasants' or farmers' resistance on a smaller scale was studied by Scott $(1981 ; 1985$; 1993), a study on peasant resistance in a village in Malaysia in the 1970s. Scott (1985) portrays various forms of daily peasants' resistance as a result of the cumulative socially diverse resistance to improve the living conditions of the farmers, which was different from the global agrarian resistance movement. This was because their daily life was filled with various class conflicts and resistances which only occasionally exploded to the surface. This means that daily class clashes and struggles will usually coincide with or be experienced with various forms of oppression that have rooted in other hierarchies.

Furthermore, Scott (1981) assumes resistance as a reaction to domination of lower or weak classes. This resistance is an explanation of the relationship between the dominant power of the rulers and those under control. This resistance is an act of the lower class or the weak to keep their existence. This means that they are "forced" to fight back because it is an effort to defend themselves as a way to survive. This resistance is a form of sustainable struggle carried out by farmers in everyday life. Scott firmly believes that power is something that is very absolute and dominant, so that it will create space for resistance. Therefore, resistance and disobedience will always come anytime and anywhere, although the space for authority contested is very narrow and congested by the variety of controls. Tracing the various spaces of lower class resistance expression will lead to the conception of 'hidden transcripts', where the discourse is behind the stage of general domination that appears in 'public transcripts' which is more subordinate to vulnerable parties, namely salt-farming farmers (J. M. Mawardi, 2016).

Scott (2000) shows that the types of resistance carried out by the lower classes (peasants) in various forms of daily life are humor, gossip, cynicism, and those done through the roots of local wisdom traditions and those various forms of resistance are part of a series of unrecorded history. Another form of resistance is verbal resistance which is informal acting as a resistance outside the stage of domination. Hence the hidden transcripts are presented as forms of discourse of gestures, speeches, and practices that are patterned outside the public transcript, in which various practices of power are subordinated. As a sequence, various practices of domination will always produce new hidden transcripts, namely fighting against the elites and corporations. Where the resistance is in the realm of struggling for various powers and interests, namely the resistance of the lower classes against attacks of false consciousness and hegemony as well as the domination of the elite or upper classes and corporations. According to Scott (1981) the conception of resistance as a concept of negation is not only sourced from a mere material basis but it also has exploitative characteristics. There is also a character of resistance to the dominant ideology as a 'counter ideological', so that hidden transcripts are not only about mere materialistic questions, but also about the agents who create and disseminate themselves.

Furthermore, according to Scott (1981) there are three forms of hidden transcripts in the form of conceptualization of social space resistance movements, namely: 1). The hidden transcript is a product or social result of the power relations between subordinates, 2). A hidden transcript like folk, culture is something that does not have a reality in pure thought, whose existence is only as an extension of social practice, social articulation, and dissemination on the outside of the social stage, and 3). The social space in the hidden transcript will grow through its efforts from various resistance. These social spaces are cultural spaces such as religion, local traditions, oral expressions, humor, gossip, folklore, which serve as a form of space for expressions of resistance and disobedience. Thus, the hidden transcript was born because of the control and fantasy in society, where this control will affect the lower class's psychological mentality due to the oppression, humiliation, injustice and other various forms of weakness. Meanwhile, fantasies about power and interests rose due to frustration and oppression, which then triggered the actions and expressions of resistance and could turn into various forms of physical resistance. 
Therefore, Scott (1993) divides the pattern of resistance in a peasant social movement into two, namely mean resistance and incidental resistance. Mean resistance has four characteristics, namely: a). more organized, systematic, and cooperative; b). principled or selfless, c). having revolutionary consequences, and d). containing ideas or goals that negate the basis of domination. This means that the resistance carried out is not always collective in nature, and the intention to survive is sometimes in the form of symbolic resistance. The incidental resistance has the following characteristics, 1). Disorganized, not systemic, and individual; 2). Speculative and profit oriented; 3). Having no revolutionary effects; and 4). Adjusting to the existing dominant system.

From this conceptualization it can be concluded that there are three categories in the form of social resistance movements according to Scott i.e. first, there is no obligation to fight back in the form of collective action; second, the social resistance movement is very complex; third, there is a symbolic or ideological resistance in doing it based on the class social structure (Mustain, 2007). This is because the characteristics of the salt farming community are very weak (farmers) so that they do not need much coordination in carrying out a social resistance movement. In fact, they often avoid direct confrontation with the authorities (Scott, 1993). Meanwhile with the expanding role of the state (PT. Garam corporation), it will also have an impact on the emergence of the transformation of the salt farming community in rural areas. This change, according Scott $(1986 ; 1985)$ is seen in three ways: a). social relations between upper class farmers and lower class farmers, where the upper class will increasingly dominate and the lower class will be increasingly subordinated. This is where the lower class resistance to the domination of the upper class or state corporations (PT. Garam); 2). The initiation of lower class's consciousness to carry out resistance movements in various forms as a form of cultural resistance; and 3). the forming of means of lower class resistance against the upper class and state corporations (PT. Garam), namely inhibiting, destroying, incitement, sabotage, burning, by ending conflicts with the awareness of collective action. Based on these various theories, this article uses Scott's theory as a surgical analysis, due to the suitability of the research locus and the daily resistance carried out. In spite of that, Scott did not explain in detail the form of cultural resistance in the daily lives of the peasants as part of social resistance, and he also put aside the element of religiosity in his resistance.

The resistance of the salt farming community as a social entity is carried out in two forms; collective and incidental resistance or disguised resistance of the salt farming community (Dzulkarnain et al., 2020). The cultural resistance of the salt farming community exists within the scope of collective resistance and incidental resistance, which is carried out collectively and in an organized pattern but has no revolutionary impact; moreover, it contains the idea of eliminating the corporate domination of PT. Garam and is adapted to the existing domination system. This cultural resistance is what the author sees in the religious tradition of 'Nyadar' in the salt farming society, which is carried out every year when the salt-making period is about to begin as a form of honor to Raden Syekh Anggasuto.

Salt as the main source of livelihood for the Pinggir Papas and Gersik Putih communities has been transformed into something worthless due to the hegemony and dominance of salt liberalism (import) by corporations and PT. Garam. Hence "Nyadar" as a religious cultural ritual tradition is now used as a means of resistance by the salt farming community through their solidarity and togetherness, as well as their attitude towards PT. Garam, the corporate and government. This is portrayed in the symbolic resistance and ideological resistance carried out by the salt farming community.

\section{METHOD}

This research has a paradigmatic constructivism i.e. a social construction between researcher individual and research subject in carrying out empathic and dialectical interactions, using qualitative research method that tends to be dialectical and hermeneutic between the researcher and the research subject (S. L. Denzin, Norman K \& Yvonna, 2009), which tries to answer questions by emphasizing how social thoughts and experiences are created and given meaning (Agusta, 2014). This study uses an ethnographic approach, in which the researcher will not attempt to theorize and consider reflexivity as something it should be, because the researcher already has what is called a 'stock of knowledge', but the researcher and the research subjects must be able to recognize, prove, and observe every other member through rationality in their real practice (Holstein, James A \& Gubrium, 1994). 
The data collection in this research was extracted from primary data sources and secondary data. The primary data were collected through participant observation and by interviewing 27 informants, as well as using focus group discussions (FGD) to each element of research actors (salt farming community, PT. Garam, and Corporates). The secondary data were obtained from official documents or available literature that were relevant and related to the research topic, such as the results of researches, books, and other documents regarding the resistance of the salt farming community. This research was carried out in Madura, precisely in Sumenep Regency, Pinggir Papas Village, Kalianget District and Gersik Putih Village, Gapura District, from August 2018 to January 2019.

\section{RESULTS AND DISCUSSION}

\section{Religious Social Life of the Madurese Salt Farming Community}

Religion in the life of the salt farming community is patterned by the education system it adopts, namely the Islamic boarding school, with a religious pattern which is a form of relationship between the Kiai or Moslem scholar, the santri (student of Islamic Boarding School), and the community, not only limited to the pattern of relations between a teacher and his students, but as a pattern of intertwined relationships with each other and one another (Rozaki, 2004). Thus, Kiai and pesantren (Islamic Boarding School) are inseparable parts of Pinggir Papas and Gresik Putih people. Studying in Islamic boarding schools has become a cultural part of the community, sometimes they even study not only in one boarding school but more than one. Many of the santris get engaged to the female student mates living in pesantren with the help of a Kiai as the intermediary. Only then, they leave boarding school to start to tive a life as a family in the community.

For the salt farming community (Pinggir Papas and Gresik Putih Village), Kiai is not only the one from whom santri get religious references, but also as the reference of social, cultural, political, and economic life. The life cycle of birth, marriage, engagement and death always involves the role of the kiai. Likewise, the success and misfortune experienced by the community always includes the role of the kiai, through his prayers and talismans, which according to the community are 'more approved and cared for' by God. Kiai who is invited to certain religious events not only gets food but also some money or known as salameten. Therefore, the discourse, ideology, and religious practices of the salt farmers in Pinggir Papas and Gresik Putih are strongly influenced by Kiai, both in interpreting religion, culture, social, economy and others. They assume that Kiai has the authoritative right to interpret the religious realm, which then affects all social and cultural communities (Pribadi, 2020).

Ideologically, the majority of Kiai's understanding adheres to Ahlussunnah Waljama'ah, based on the theology of Abu Hasan Al-Asyari and Abu Mansur Al-Maturidy, muamalah (fiqh) refers to Imam Shafi'i, even though they acknowledge the understanding of other fiqh imams, such as Imam Hanafi, Imam Maliki, and Imam Hambali. In the religious field Sufism refers more to Ghazali and Junaid AlBaghdadi (Djauhari, 1996). The ideology of Ahlussunnah Waljama'ah as embraced by the community and the Nahdlatul Ulama 'Ulama' (NU) in Madura, in the process of interpreting Islamic law (istinbatul hukm), by using a balance between the Naqli argument and the aqli argument as well as the culture that developed in the community as a society in the process of interpreting Islamic law (istinbatul hukm) the main reference. Even religious traditions syncretize with local culture through religious media (Hefni, 2019). In addition, in Madura also developed three tarekat, namely the Naqshabandiyah tarekat, Qadiriyah wa Naqshabandiyah, and Tijaniyah (Bruinessen, 1995), which then formed a network between Kiai in Java and Madura (Suwito \& Muhbib, 2002).

Religious rituals, for example, the media of tahlilan are not only used as religious media which are oriented towards respecting the deceased or remind us of the greatness of God through signs of death, but also as a means of social outreach that brings people together. In tahlilan the Kiai acts as the main actor, because he is the one who recites the tahlil prayers followed by the congregation present. The respect of the salt farming community (Pinggir Papas and Gresik Putih) for their ancestors, seen by respect for buju' or asta (the tombs of the ancestors), such as asking for marriage blessing to Buju' Saleman (in Gresik Putih village) and asking for the success of salt harvest by conducting a Nyadar ritual in asta Raden Anggasuto (in Pinggir Papas village). 


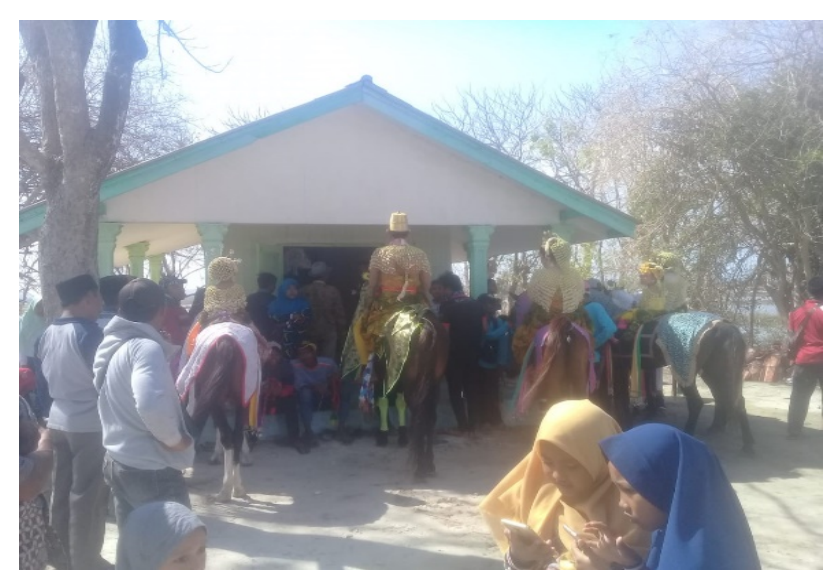

Figure 1: The blessing of buju' Saleman

In addition, the respect of the salt farming community towards the spirits of their ancestors through the tradition of necromance or through the medium of tahlilan, which is carried out in a communal slameten manner. This cultural practice takes place for seven days, the participants do not get special invitation, because this salvation is better understood as a communal party that is open in nature, so that it involves citizens of all ages and all men. The offerings provided in the salvation that are served to the residents of the tahlilan participants at telok arena (day 3), and pettok arena (day 7), seem to be more privileged than the other days. The leaders of this tahlilan are usually a Kiai or community leader. Besides pettok arena, other times that are considered special to honor the spirits of the ancestors are the pakpoloh arena (the $40^{\text {th }}$ day), satos arena (the $100^{\text {th }}$ day), nataon (one year the day of his death), and nyaebuna (the $1000^{\text {th }}$ day) (Rifa'i, 2007). Even so, there are some members of the community who respect the spirits of their ancestors, namely every year the death of his family or often called a haul. However, those who carry out the tradition are only those who are economically capable, and are regarded as community leaders (politics) or Kiai families (Pribadi, 2018).

This means that in terms of the socio-cultural structure of the salt farming community (Pinggir Papas and Gresik Putih) in general has a unique culture. One side of its culture is influenced by Islamic culture as an embodiment of Kiai's leadership through his boarding school education, such as gambus, hadrah, samman etc. and social culture such as carok culture, kerapan sapi, bèbertèn, sandeghâ bhumi, topeng, lodrok and so on. Therefore, Mark R Woodward (Woodward, 2002), did not call it pure Islam but "local Islam". In other words as the influence of Islamization in Java, the development of Islam in the salt farming community (Pinggir Papas and Gresik Putih) prioritizes learning syncretization of Islamic shari'ah which uses sufism and local knowledge predominantly (Taufiqurrahman, 2007). As village elites, both (Kiai and blater) mutually do various ways to gain influence, sympathy, and power from the community. The Kiai's approach is generally through discourse, rituals and religious symbolization, while blater through his ability to use instruments of violence (Rozaki, 2004).

\section{Hegemony and Domination of Liberalization of Madurese Communities}

The hegemony and domination are strongly portrayed through the monopoly system carried out by the VOC (Netherlands Indies Trading Company), by buying up trade and production of salt, and monopolizing salt imports (de Jonge, 2012). Salt was one of the most important industries that generated a lot of profit, when the supply was manipulated (de Jonge, 2012). Monopolies were further strengthened and tightened to avoid the types of fraud committed by the previous contractors (Raffles, 2014), during the British transitional administration (1811-1816), namely the zoutregie monopoly. Where all salt production belonged to the government, the price had been determined by the government and the salt that had been collected must be immediately sent to the warehouses. Anyone who committed defiance, including hidden hoarding, will be severely punished. Every stockpiling would be confiscated by the government, and transportation that exceeded one bag of salt $\pm 61.7 \mathrm{Kg}$ 
would be asked for a travel document (de Jonge, 2012), not even people's homes were allowed to store salt, because it would be confiscated and punished. ${ }^{1}$

Entering the period of independence, the abolition of the salt monopoly with the issuance of Emergency Law No. 25 of 1957 turned out to be compulsorily and handsomely paid due to the collapse of the order of production and distribution of salt farming that had been carried out since the reign of Dutch colonialism. This had an impact on the emergence of endemic diseases of iodine deficiency disorder, namely goiter, and so on. Indonesia at the beginning of its independence could not control the production and distribution of salt, including the quality of the salt produced although, at this time the Madurese salt farming community returned to producing krosok (coarse salt) which they could trade on their own without any supervision from the government. People bought krosok salt at a lower price, but the quality of the salt was not good. The difficulty of the economy at the beginning of the independence made them ignore their health, because it was difficult to get good and nutritious consumption, including iodized salt (Rochwulaningsih, 2008).

With the intervention of the international donor agency WHO and with the sponsorship of UNICEF, to escape the disturbance caused by iodine deficiency (GAKY), the Indonesian government of the New Order regime issued Presidential Decree No. 69 of 1994 concerning the obligation to iodize salt. The seriousness of the government to be free from disturbances of iodine deficiency can be seen from the socialization carried out by the New Order government and national surveys in 1995-1996 and 19971998, which showed a decrease in the prevalence of IDD from 30 percent to 14 percent (Indonesia, n.d.). This survey was conducted by the Central Bureau of Statistics (BPS) supported by CIDA and assisted by WHO and UNICEF to evaluate the performance of the Indonesian government in overcoming IDD (Rochwulaningsih, 2008).

The success of the Indonesian New Order government to program iodized salt had an impact on the economic condition of the Madurese Salt farming community. The salt iodization policy marked the beginning of salt import in Indonesia. This condition had an impact on the co-optation of salt in the global economic power, where iodine chemicals must be imported and their distribution to the industry was monopolized by companies close to the New Order government, namely PT. Kimia Farma (Rochwulaningsih, 2008).

Apart from that, the iodized salt policy had also an impact on the emergence of polarization for the salt industry companies, namely the small salt industry and the big salt industry. The obligation for iodized salt had an impact on the long chain of salt production process from krosok (coarse /raw) salt produced by the salt farming community, which eventually had an impact on the higher cost of the production process. Then, coupled with iodized salt raw material which was only monopolized by certain companies with strong network access as well as strong economic and political capital, small salt industries were further eliminated (Rochwulaningsih, 2008). This can be seen from the absence of a small salt industry in Madura (Sumenep) ${ }^{2}$, a portrait of death in global economic competition. This means that the success of the New Order Indonesian government in overcoming IDD which was sponsored by WHO and UNICEF did not have an impact on increasing the production of small salt industries to be more competitive in the global economic level.

Then, the salt iodization program was also followed by capital-intensive technology, which was also monopolized by certain companies that had network access, strong economic and political capital, as well as capital from Western (foreign) countries, which then had an even greater impact on the collapse of the people's small salt industry. This turned into a victory of the liberalistic capitalist salt industry companies.

The fall down of the small salt industry and the victory of the salt companies, with their capital strength and network access, further strengthened the monopolistic trading system of the salt companies, the liberalistic character of capitalism. However, there has been a polemic among the Ministry of Maritime and Fisheries, the Ministry of Trade, and the Ministry of Industry related to the amount of salt import need every year as in 2018 (2019-2020), The Ministry of Maritime and Fisheries (KKP) recommended importing 2.2 million tons of salt meanwhile the Ministry of Industry

\footnotetext{
${ }^{1}$ Interview with Ramli, a community leader in Marengan Kalianget Sumenep, 25 September 2019

${ }^{2}$ Interview with Ki Kabrawi, a former worker (pantong) at Pegaraman land since the Dutch colonialism era, 23 July 2019
} 
recommended as much as 3.7 million tons; on the other hand, the Ministry of Trade permitted 21 companies to import 2.37 million tons ("Polemik Impor Garam Tak Kunjung Usai," 2018). The tendency of Indonesia government to import excessively by ignoring the domestic production of salt which had increased since 2017 made the price of the people's salt decrease sharply (Rochwulaningsih, 2008).

The need for national salt which tends to increase, both for consumption and industry, and the 'monopoly' carried out by big salt companies to meet national salt needs give a portrait that the government tends to be capitalist liberalists that can 'kill' small industrialization of the people's salt production. This is portrayed from the mastery of national salt production which tends to be controlled by a handful of companies with the strongest capital and network access, which according to The CDMI Consulting Group in table 1 (The CDMI Consulting Group, 2019), the leader of salt production in Indonesia involves nine large companies, both in the category of industrial salt and consumption salt. The mastery of this production will also have an impact on the control over salt imports.

Table 1 Production Capacity of Salt Company, 2018

\begin{tabular}{lllllll}
\hline \multirow{2}{*}{ No. } & Company & \multicolumn{3}{c}{ Salt Type } & $\begin{array}{l}\text { Total } \\
\text { (Ton) }\end{array}$ & $\begin{array}{l}\text { Share } \\
100 \%\end{array}$ \\
\cline { 3 - 6 } & & Consumption & Industry & Others & 164,000 & 4.5 \\
\hline 1. & $\begin{array}{l}\text { PT. Budiono Madura } \\
\text { Bangun }\end{array}$ & Persada & 152,000 & 12,000 & - & \\
2. & PT. Cheetam Garam Indonesia & 50,000 & 160,000 & - & 210,000 & 5.7 \\
3. & PT. Garam & 350,000 & - & - & 350,000 & 9.6 \\
4. & PT. Garindo Sejahtera Abadi & 575,000 & 200,000 & 150,100 & 925,100 & 25.3 \\
5. & PT. Kimia Farma & - & 6,000 & - & 6,000 & 0.2 \\
6. & PT. Niaga Garam Cemerlang & 18,000 & 60,000 & - & 78,000 & 2.1 \\
7. & PT. Saltindo Perkasa & - & 75,000 & - & 75,000 & 2.1 \\
8. & PT. Sumatraco Langgeng Makmur & 285,000 & 430,800 & - & 715,800 & 19.6 \\
9. & PT. Susanti Megah & 439,700 & 150,000 & - & 589,700 & 16.1 \\
10. & PT. Unichemcandi Indonesia & - & 340,000 & - & 340,000 & 9.3 \\
11. & Others & 200,000 & & & 200,000 & 5.5 \\
& Total & $2,069,700$ & $1,433,800$ & 150,100 & $3,653,600$ & $100 \%$ \\
\hline
\end{tabular}

Source: (The CDMI Consulting Group, 2019)

Regulatory policies that tend to be manipulative by benefiting state embodiment companies (PT. Garam) and private salt companies, with the elimination of the salt farming community's small salt industry are basically supported by regulative policies implemented since the Indonesian government of the New Order regime, intervened by international institutions WHO and UNICEF. The issuance of Presidential Decree No. 69 of 1994 is the beginning of a manipulative trading system. This decision has caused the salt trading system to be manipulated by PT. Garam because all production produced by the salt farming community must go through standardization by PT. Garam, and thus the people are not allowed to sell and buy their salt production without the standardization process carried out by PT. Garam.

Since then, the salt farming community has not been given the freedom to sell their salt product, because salable salts must have a standard set by the Presidential Decree, iodine and $\mathrm{NaCl}$ in accordance with established health standards, to obtain the Standards Indonesian Industry or Indonesian National Standard (SNI). Thus, every krosok salt (crude salt) produced by the salt farming community must be washed and iodized, and then packaged and labeled before being sold to public. This is where the monopolistic policy and support for companies that own capital is very visible, because all processing, packaging and labeling can only be done by PT. Garam, private companies, and cooperatives appointed by the Minister of Industry, including their products sale (The CDMI Consulting Group, 2019). 
Consequently, the people's salt product is not competitive compared to the salt produced by PT. Garam and private salt companies. It turns out that with this policy, most of the companies are reluctant to buy the people's salt which contains less than $92 \% \mathrm{NaCl}$, meaning that the salt product does not meet the SNI qualifications. Therefore, to fulfill the national and companies salt needs, the government import both consumption and industrial salt even though the salt produced by the salt farming community is sufficient, and the production has increased a lot since the introduction of the use of geomembrane. This can be seen in Table 2 below (Rochwulaningsih, 2008).

Table 2 National Salt Production

\begin{tabular}{llll}
\hline Year & Total & PT. Garam (Ton) & People's Salt (Ton) \\
\hline 2013 & $1,087,715$ & 156,829 & 930,886 \\
2014 & $2,192,168$ & 315,000 & $1,877,168$ \\
2015 & $2,531,596$ & 345,000 & $2,186,596$ \\
2016 & 144,009 & 25,600 & 118,409 \\
2017 & 916,900 & 198,000 & 718,900 \\
2018 & $2,719,256$ & 369,626 & $2,349,630$
\end{tabular}

Source: (The CDMI Consulting Group, 2019)

\section{Nyadar: Religious Ritual and Resistance of Madurese Salt Farming Community}

Nyadar which is a form of religious cultural activity carried out by the Madurese community as a form of petition and gratitude from the community of salt farmers for starting and completing salt production. Nyadar is taken place three times a year. First, the nyadar ceremony is usually carried out in July, in which the salt production starts, the readiness to process (tua) sea water onto crystal ponds. The second nyadar event is performed in August, which is the peak of salt production (salt collection). This religious cultural ritual is often referred to as a form of flower sowing ceremony performed on Friday. Nyadar ritual usually starts around 04:00 p.m (Suhelmi, et al, 2013).

The Madurese community prepares all equipment (Suhelmi, et al, 2013) by providing chicken or milkfish as rasol nyadar as part of the offerings, but not all chicken meat has yet to be included in nyadar ritual, because sometimes it contains dog meat, pork and throat meat. ${ }^{3}$ After Friday prayer the people of salt farmers community began gathering to Buju 'Ghubhang cemetery in figure 2, which consists of the graves of Sheikh Raden Anggasuto, Emba Kabasa (Kuasa), Emba Bangsa, and Emba Dukun (youngest ancestor). Arriving at the burial site of Buju 'Ghubhang (in figure 2), the Madurese community give a sontengan ${ }^{4}$ to the representatives of their respective groups. ${ }^{5}$

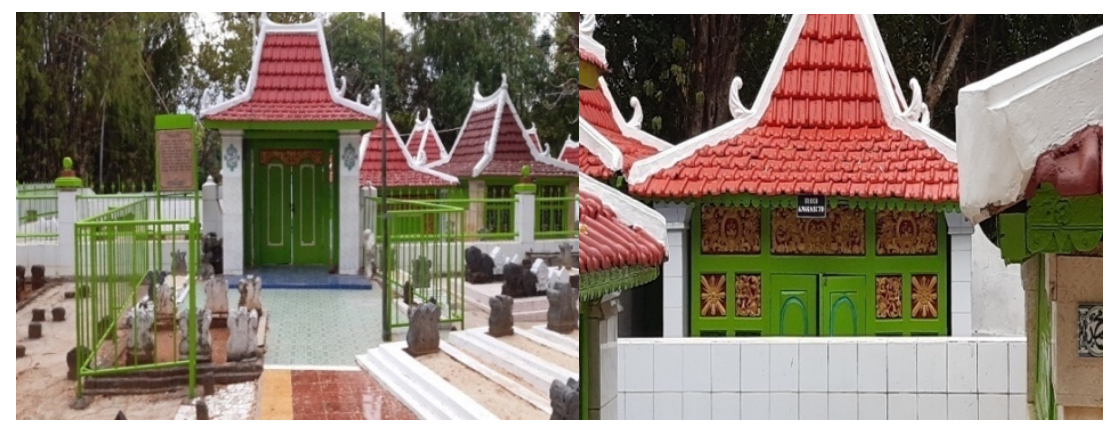

Figure 2 Buju’ Ghubâng Cemetery

${ }^{3}$ Equipments in nyadar religious cultural ritual: rice, raw chicken meat, milk fish, spices, firewood, trays, panjhâng (large plates), and tanggi' (half-round long-covering panjhâng made of woven palm leaves and painted red with a black circlein the middle). See, (Hefni, 2019: 204)

${ }^{4}$ Parts of chicken that should not be included: dog meat and pork (chicken leg and right leg), throat meat (chicken breast, intestine, chicken feet), (Hefni, 2019: 202-203)

${ }^{5}$ Sontèngan consists of slices of cananga and pandanus leaves, powder granules, grains of incense, and pangsa (sum of money), all of which are wrapped in banana leaves, (Hefni, 2019: 204) 
Before sowing flower ceremony, an important cultural religious ritual in nyadar must be performed, which is scrambling to enter the cemetery of the ancestors to offer prayer, because for the Madurese community, entering the ancestral tomb will speed up the acceptance of the prayer. They struggle to seize the powder solution, by dipping the index finger into the powder solution to eat and the rest applied to some parts of the face as a sign to their ancestors that they participate in nyadar event. Then they offer prayers to the ancestors, because the ancestors are nicknamed Allah, guardians, and apostles. Because the ancestor's position is very high, whatever is requested will be granted by the ancestors (Hefni, 2019).

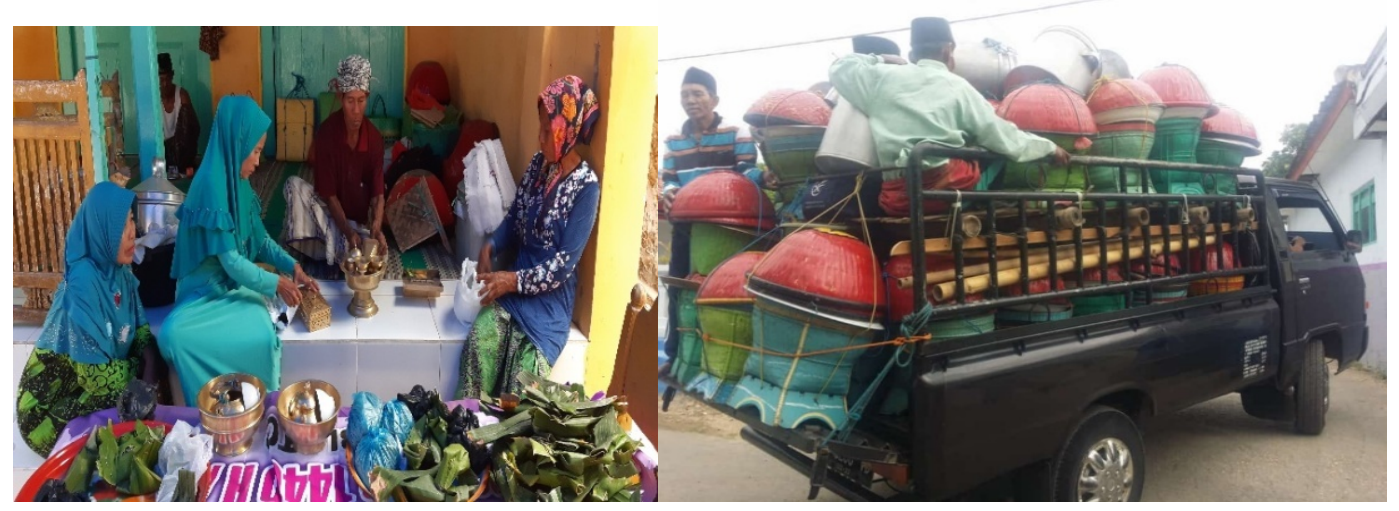

Figure 3 Preparations for Nyadar Ceremony: The Collection of Flowers and Offerings; Carrying Nyadar Ritual Provisions towards the Location of Ritual Tradition

In the evening the salt farmers gather and stay overnight in the houses of the residents of Kebon Dadap Village, Saronggi District, Sumenep Regency, Madura, which is adjacent to the Buju' Ghubhang complex. At night the salt farming community prepare rasol nyadar (offerings) for their own consumption for the following day (Saturday morning). Cooking rice, frying chicken meat, milkfish, and egg omelette, and cooking five-color tajin (porridge), namely potè (white porridge) as a symbol of purity symbol, tajin mera (red porridge) means symbolic as courage, tajin celleng (black porridge) as a symbol of temptation for humans, tajin bhiru dhaun (green porridge) means symbolic as a symbol of patience and truth, and tajin konèng (yellow porridge) as a symbol that means calmness in facing of various trials. All food preparations are pepared by the women. ${ }^{6}$ After the dishes are ready, then the next task is preparing the tools for the dishes for nyadar ceremony in the next morning (Saturday). This preparation is done by men. Washing panjhâng with prayer specifically (Hefni, 2019), a rice cone will be placed on it, and during the process of making it prayers are conveyed. ${ }^{7}$ The cone symbolyzes fertility and prosperity that will lead to true glory. The top of the cone is a portrait of God's transcendentalism to give prosperity power to the people of salt farming community. The pile is placed with a few pieces of fried chicken, fried milk fish, and an omelette that depicts the shining sun, since the central symbol of the process of making salt is the sun. When placing the chicken meat ${ }^{8}$ and eggs, ${ }^{9}$ a special prayer is also offered to God. Then the panjhang is placed on a tray which has been spread with banana leaves on it accompanied by prayers. ${ }^{10}$ Having completed the rasol nyadar offerings, the foods are covered with tanggik. In doing so, special prayers are offered ${ }^{11}$ to prepare the nyadar ceremony the next day (Saturday) (in figure 3).

\footnotetext{
${ }^{6}$ Interviewing with Edi, Community Figure of Pinggir Papas and Owner salt farming land, 19 September 2019

${ }^{7}$ The Prayer 'Bismillahirrohmanirrahim, holly earth holly sky merk ka Great Blessing holly laila......Ya Muhammad', (Hefni, 2019: 208)

${ }^{8}$ The Prayer 'Bismillah....I intend to fill the panjhâng, holly gifts perfect physical kamorana'ah kaoladhâna'ah geddung parèntah tatemmoah gung kobasah Anggasuto tatemmoah soarghâloka bidaddarih se nyandingèh Allah se nyateddih sadbasidad porbabisidad potrè Adi Potrè Konèng......laila Ya Muhammad', (Hefni, 2019: 208)

${ }^{9}$ The Prayer 'Aku angonggaginah lur laila....... Ya Muhammad', (Hefni, 2019: 209)

${ }^{10}$ The Prayer laying banana leaves 'Bismillah.......niat ingsung ngamparah sere raddin, laila .......Ya Muhammad',(Hefni, 2019: 209)

11 The Prayer 'Aku napongah langngè' kalabân bhumi, laila.......Ya Muhammad', (Hefni, 2019: 209)
} 
On Saturday with the tanggik containing rasol nyadar, the Madurese salt farming community return to the Buju' Ghubhang complex. All the people are seated, and then one of the chiefs dressed in racok saèbu (colorful) and odheng batik on his head counts the panjhang, which consists of 777 panjhangs and the number has remained the same from the past until the present time. After counting the panjhang, he reports it to the leaders of the nyadar ceremony, consisting of the descendants of Emba Raden Sheikh Anggasuto, Emba Kabasa, Emba Shaman, and Emba Bangsa. After everything is ready, the leader of nyadar offers a prayer ${ }^{12}$ for the blessing and prosperity obtained by the Madurese salt farming community. After the recitation of the prayer finishes the Madurese salt farming community eat the rasol nyadar. The rest of uneaten rasol nyadar is taken home and shared with other family members or neighbors. Meanwhile, the third cultural religious nyadar ceremony takes place in the residence of Syekh Raden Anggasuto, by reading macapat telling Jatiswara story in old Javanese language written on lontar (palm) leaves, which tells about the journey of life and body in human life, and also reading Sampurnaning Sembah which tells about the piety and excellence of humans to God (Indonesia, n.d.).

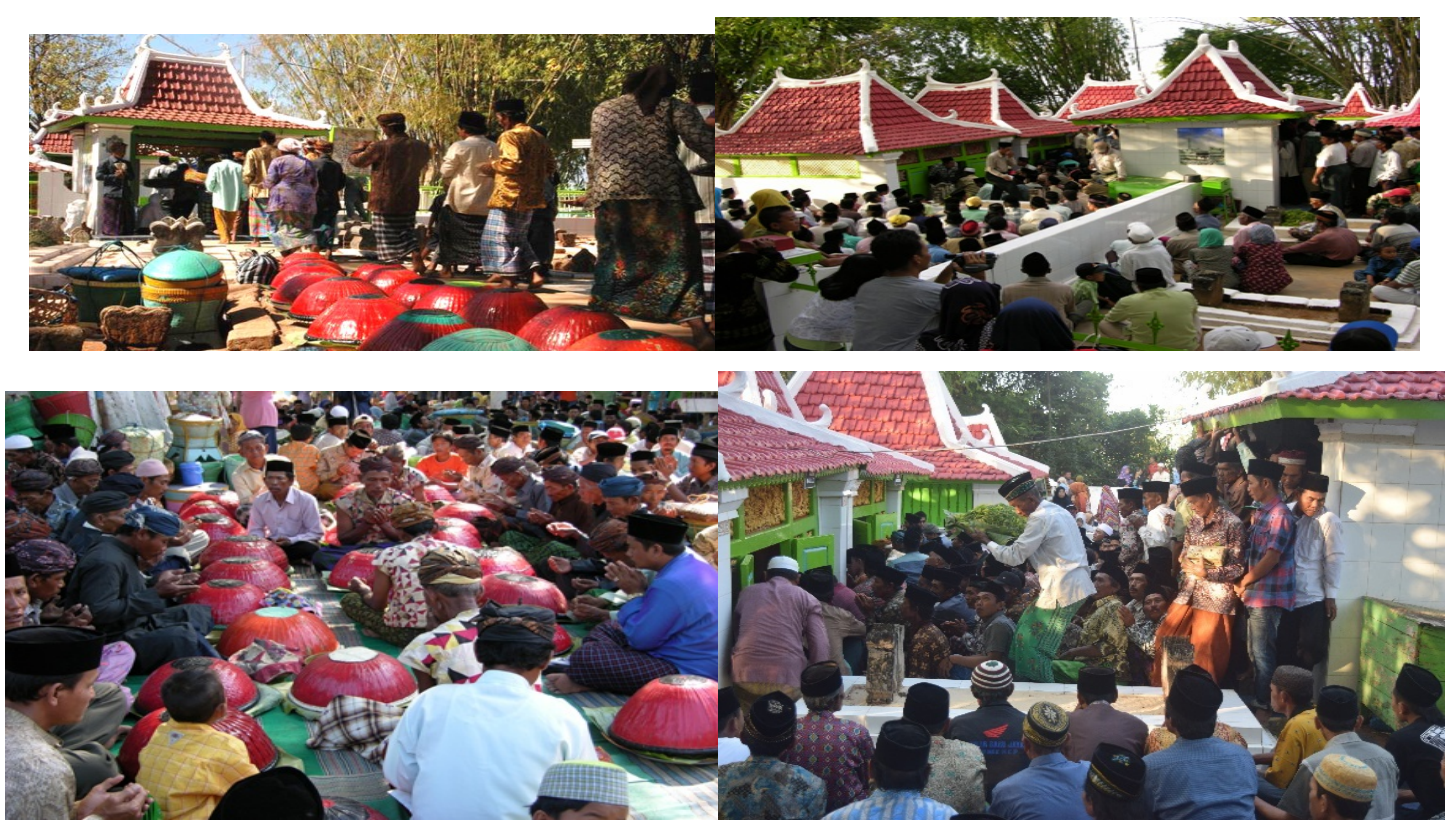

Figure 4 Nyadar Religious Cultural Rituals

12 This prayer begins with the recitation of tawashul surah al-Fatihah, reciting Surah Al-Ikhlas, Surah AlFalaq, and Surah An-Nas, the first seven verses in Surah Al-Baqarah. After that, they pray and follow 'aamiin' by the Madurese community...'Bismillahirrohmanirrahim....Allahumma shalli ala Muhammadin wa ala ali Muhammad wa khotaman Nabiyyina wa riyallahu ta'ala an sadatina rasullullahi ajma 'in.... 'Bismillahirrohmanirrahim.....Allahumma shalli sadâ ing kabi adur rahmat du'a ning pandita salam kabi ing Rasulullah. Tamba asung narajekkèh ummat kang malaratan iyyaka na'budu wa iyyaka nasta'in. Yadir yadur anyekken ban Allahu syada walana yahu birohmatika ya arhamar rohimin.....'Bismillahirrohmanirrahim......Allahumma ma'repati nujum ma'repatullah millati nujum kandil sirullahi sil Muhammad. Allahu tunaku, sung barèknasung. Barang kusung kita padhâ olleya rahman Rahim. Mintalah wâjjâh wâjjâh say in lahu yahu. Birohmatika Ya Arhamar Rohimin....'Bismillahirrohmanirrahim.....Allahumma antu' datèng ning pandhita, doaning wali, doaning mukmin, doaning ratu ummat kang malaratan duambarsari sarining bumi sarining langit, sallallahu alayhi wasallam. Birohmatika Ya Arhamar Rohimin....'Bismillahirrohmanirrohim.....Aallahumma wajibul umur napdul ning panca bâjâh wa andur bâdur manjingna umur. Asih asih salamet ing pangandika ing Rasulullah, Ya Allah Ya Rasulullah. Birohmatika Ya Arhamar Rohimin....'Bismillahirrohmanirrahim....Allahumma ambarsari sarining bumi kang asumber ka sitti, kang asumber bukti bumi kawâsah, adz-Dzat sampurna ruheh ummat tul ya Rahmat, ummating nabbi Muhammad Sallallahu alayhi wasallam. Birohmatika Ya Arhamar Rohimin.... 'Bismillahirrohmanirrahim....Allahumma sepat jâmak, sepat dunyâ, sepat akherat, cahyâ Nabbi cahyâ Muhammad, cahyâ Allah, sallallahu alayhi wasallam. Birohmatika Ya Arhamar Rohimin.... 'Bismillahirrohmanirrahim....Allahumma farek kulubuna man farek kulubuhum, wa nawir kulubuna wa nawir kulubuhum, kama barakta kuburana. Birohmatika Ya Arhamar Rohimin', (Hefni, 2019: 211-212) 
Nyadar ritual for Madurese salt farming community is not only a cultural ritual ceremony or merely a religious mystical ritual (in figure 4) to give respect to their ancestors but also an event in which there are symbols of togetherness among Madurese salt farming community to enjoy, appreciate, and give respect to the values of 'salt' prosperity they obtain, although they realize that they still live in poverty. Poverty is not to be mourned but it is something that has to be 'changed' into prosperity for the community's life by relying on the salt production (The Result of FGD with Salt farming community of Pinggir Papas, 07 August 2019).

Through the phases of the cultural or religious ritual, togetherness for the salt farming community who are on 'the same boat' in increasing their prosperity has triggered the spirit of 'resistance' for the salt farming community. The oppressions, powerlessness, poverty, and the problems they face such as farm lands seizure, the cheap price of salt, low labor wages, and low-distributed salt production are the roots of the problems faced by the Madurese salt farming community. Through the religious nyadar ceremony, the salt farming community as the subordinated community is struggling to escape from the oppressions and injustice. The solidarity and transcendental wishes to God and ancestors are the portraits of a cultural resistance performed by the Madurese salt farming community. This can be seen from the community's refusal to make nyadar ceremony be included as part of the cultural tourism visit program in Sumenep Regency. It is because nyadar as religious culture is performed based on the nature namely the movement of Porteka (Kartika) star and Nanggala (Bajak) Star, and finally the fixed ritual time is determined by the custom chief (the descendant of Syekh Raden Anggasuto). ${ }^{13}$

Nyadar has been a big ceremony for the salt farming community in Madura. It is even more lively compared with Idul Fitri or Idul Adha in Islamic celebration. It is believed that by participating in nyadar ceremony three times in a row, they will get merits equal to a hajj pilgrimage, and the site of Syekh Raden Angggasuto's grave is considered to be a place in higher position than Mecca (a place for hajj pilgrimage). ${ }^{14}$ Nevertheless, during the glorious period of salt production, many of the salt farmers could afford to perform hajj pilgrimage to Mecca. This is a portrait of 'cultural religious' resistance of Madurese salt farming community against the powerlessness, oppression, and poverty fettering them. The cost of hajj pilgrimage is so expensive that the salt farming community cannot afford to pay for it; therefore, the religious and cultural ritual of nyadar is a form of solidarity solution of 'religious cultural resistance' done by the community (in figure 5).

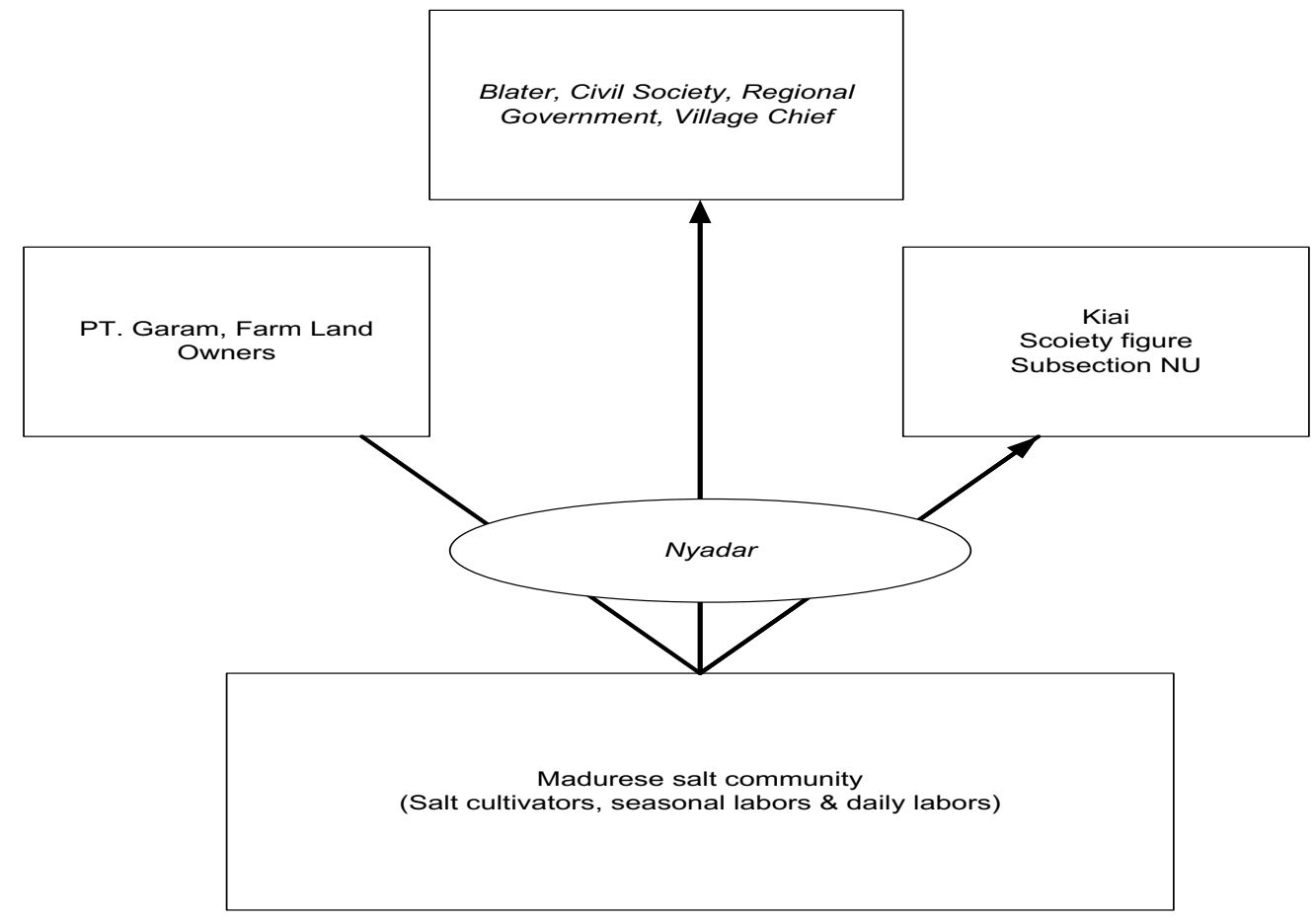

Figure 5. The Pattern of Cultural Resistance of Madurese Salt Farming Community

${ }^{13}$ Interviewing with Suhrawi, the Secreatry of Pinggir Papas Village who serves temporarily as the Village Head of Pinggir Papas, 19 September 2019

${ }^{14}$ Interviewing with Kiai Fathor, the Cemetery Attendant (door-keeper) of Syekh Raden Anggasuto, 12 Agustus 2019 
Nyadar as a cultural expression of Madurese salt farming community (Pinggir Papas and Gresik Putih Village) has been a form of cultural resistance against the domination and hegemony of higher class (land owners), elites (the government, Kiai, etc.), and corporate (PT. Garam). The celebration of nyadar, the cultural religious ritual by the salt farming community is a portrait of an ideological counter' against the exploitation done by the elites, higher class, and corporate towards the Madurese salt community (slave laborers).

\section{CONCLUSION}

Salt liberalization which has an impact on the more strengthened hegemony and domination of the salt farming corporate on land ownership as well as the production and sales of salt has caused helplessness and poverty to the Madurese salt community. Nyadar appears in annual religious ritual as a form of solidarity to do collective actions to actualize their existence. Eventually, nyadar has turned into a form of cultural resistance as a portrait of the consciousness of the lower class community to use the religious cultural social spaces in expressing the community's resistance and disobedience towards the corporate (PT. Garam), local elites, and salt farm land owners. These resistances are portrayed in the counter ideology regarding the hajj. For the Madurese salt farming community with a variety of economic powerlessness, the hajj is likened to the participation of the salt community in the religious ritual of nyadar for three consecutive years. In addition, this resistance is also portrayed in the form of rejection of various policies imposed by the government regarding the ceremony of religious cultural rituals of nyadar i.e. the rejection against the involvement of PT. Garam and the salt corporation to get involved in the celebration of nyadar. For examples, the refusal to make Nyadar as religious and cultural ritual tradition become part of religious tourism destinations and the refusal to schedule Nyadar ceremony consistently and permanently to facilitate the tourism promotion carried out by the Government of Sumenep Regency. For the salt farming community, nyadar is a sacred religious ritual ceremony to commemorate Syekh Raden Anggasuto's merit in finding salt as the main source of livelihood for the salt farming community. Therefore, the salt farming community rejects anyone who has taken the source of people's livelihoods, namely salt in the form of monopoly, hegemony, or policies that do not side with the salt farming community, to become part of the religious ritual or cultural rituals of nyadar, because they will disrupt the sacredness of nyadar. This cultural resistance has created the salt farming community's awareness to get together in solidarity through the religious ritual tradition of nyadar.

\section{ACKNOWLEDGEMENT}

This article is a part of the dissertation of Rural Sociology graduate programme, IPB University. The writer expresses his gratitude to LPDP Ministry of Financial Affairs of the Republic of Indonesia who has granted the scholarship and funded the dissertation research.

\section{REFERENCES}

Agusta, I. (2014). Paradigma Metodologi Ilmu Sosial: Simpang Jalan Konstruksi Teori. IPB Press.

Anshory Ch, H. N. (2008). Bangsa Inlander: Potret Kolonialisme di Bumi Nusantara. LKiS.

Baekhaki, K., Kinseng, R. A., \& Soetarto, E. (2015). Corporatization of Salt Farmer: The Dynamic of Social Economic and Ecological Transitions. Sodality: Jurnal Sosiologi Pedesaan, 6(1), 61-70. 
Bernstein, H. (2015). Dinamika Kelas dalam Perubahan Agraria: Seri Kajian Petani dan Perubahan Agraria. Insist Press.

Boenarco, I. S. (2012). Kebijakan Impor Garam Indonesia (2004-2010): Implikasi Liberalisasi Perdagangan Terhadap Sektor Pegaraman Nasional. UI.

Bruinessen, M. van. (1995). Kitab Kuning: Pesantren dan Tarekat Tradisi-Tradisi Islam di Indonesia. Mizan.

de Jonge, H. (1991). Streotype of the Madurese. International Workshop on Indonesian Studies.

de Jonge, H. (2004). State and Welfare in the Late Colonial Period: The Madura Welfare Fund (1937-1941). Asian Journal of Social Science, 32(1), 91-103. https://doi.org/10.1146/annurev.anthro.34.081804.120633

de Jonge, H. (2012). Garam, Kekerasan dan Aduan Sapi: Esai-Esai tentang Orang Madura dan Kebudayaan Madura. LKiS.

Denzin, Norman K \& Yvonna, S. L. (2009). Hand Book of Qualitative Research. Pustaka Pelajar.

Dick, H. W. (1998). Sejarah Ekonomi Modern Indonesia: Berbagai Tantangan Baru. In J. T. Lindblad (Ed.), Industrialisasi Abad ke 19: Sebuah Kesempatan yang Hilang. LP3ES.

Djauhari, M. T. (1996). Peran Islam dalam Pembentukan Etos Masyarakat Madura. di dalam Mahasin, A (Ed.). Ruh Islam dalam Budaya Bangsa: Aneka Budaya di Jawa. Yayasan Festival Istiqlal.

Dzulkarnain, I., Soetarto, E., Kinseng, R. A., \& Sjaf, S. (2020). Disguised Resistance of Madurese Salt Farming Community. Agriekonomika, 9(1), 100-113.

Fajariyah, D. (2016). Sengketa Tanah Tambak Garam di Simpang Tahun 2005-2012. Pendidikan Sejarah, 4(3), 1095-1109.

Hefni, M. (2019). Islam Madura: Sebuah Studi Konstruktivisme-Strukturalis tentang Relasi Islam Pesantren dan Islam Kampung di Sumenep Madura. Literasi Nusantara.

Helmi, A., \& Sasaoka, M. (2018). Dealing with Socioeconomic and Climate-related Uncertainty in Small-scale Salt Producers in Rural Sampang, Indonesia. Journal of Rural Studies, 59 (June 2017), 88-97. https://doi.org/10.1016/j.jrurstud.2018.02.005

Herkusumo, A. P. (n.d.). Chuo Sangi-in Dewan Pertimbangan Pusat Pada Masa Pendudukan Jepang. Rosda Jayaputra.

Holstein, James A \& Gubrium, J. F. (1994). Phenomenology, Ethnomethodology, and Interpretive Practice. In L. S. Denzin, Norman K \& Yvonna (Ed.), Handbook Qualitative Research. Sage Publication.

Indonesia, N. G. (n.d.). Hikayat Garam: Sebutir Garam untuk Kehidupan di Bumi Seribu Masjid (N. G. Indonesia (Ed.)). Bank Mandiri.

J. M. Mawardi. (2016). Perlawanan Petani Terhadap Ketidakadilan Agraria dalam Stigma Gerombolan Pengacau Keamanan (Studi Pada Masyarakat Talangsari Lampung Timur). IPB.

Kanumoyoso, B. (2001). Nasionalisasi Perusahaan Belanda di Indonesia. Pustaka Sinar Harapan.

Kasdi, A. (2003). Perlawanan Penguasa Madura Atas Hegemoni Jawa: Relasi Pusat-Daerah Pada Periode Akhir Mataram (1726-1745). Jendela.

Kuntowijoyo. (2002). Perubahan Sosial dalam Masyarakat Agraris Madura 1850-1940. Mata 


\section{Bangsa.}

Kurniawan, B. A. (2016). Implementasi Program Dana Bantuan Pemberdayaan Usaha Garam Rakyat (PUGAR) dalam Rangka Pengembangan Wirausaha Garam Rakyat (Studi Pada

Dinas Kelautan dan Perikanan Kabupaten Sumenep). Ajie, 1(1), 11-29. https://doi.org/10.20885/ajie.vol1.iss1.art2

Kurniawan, T. dan A. A. (2013). Dampak Kebijakan Impor dan Kelembagaan Terhadap Kinerja Industri Garam Nasional. Jurnal Kebijakan Sosek, 3(1), 1-13.

Landsberger, H. A \& Yu, G. A. (1981). Pergolakan Petani dan Perubahan Sosial. Yayasan Ilmu-ilmu Sosial dan Rajawali Press.

Mustain. (2007). Petani VS Negara: Gerakan Sosial Petani Melawan Hegemoni Negara. ArRuzz Media.

Nurhajarini, D. R. et al. (2005). Kerusuhan Sosial di Madura Kasus Waduk Nipah dan Ladang Garam. Kementerian Kebudayaan dan Pariwisata Deputi Bidang Pelestarian dan Pengembangan Kebudayaan Balai Kajian Sejarah dan Nilai Tradisional Yogyakarta.

Parwata. (1997). Monopoli Garam di Madira 1905-1920. BPPS UGM, 10(1a), 135-147.

Parwoto, P.-. (2018). Dampak Monopoli Garam di Madura Pada Abad XX. MOZAIK: Jurnal Ilmu-Ilmu Sosial dan Humaniora, 7(1), 33-42. https://doi.org/10.21831/moz.v7i1.6182

Polemik Impor Garam Tak Kunjung Usai. (2018). CNBC Indonesia.

Pribadi, Y. (2018). Islam, State and Society in Indonesia: Local Politics in Madura. Routledge.

Pribadi, Y. (2020). Islam Madura: Sebuah Studi Konstruktivisme-Strukturalis tentang Relasi Islam Pesantren dan Islam Kampung di Sumenep Madura, by Mohammad Hefni. Bijdragen Tot de Taal-, Land-En Volkenkunde / Journal of the Humanities and Social Sciences of Southeast Asia, 176(2-3), 429-431. https://doi.org/10.1163/2213437917602009

Rachman, A. J. (ed.). (2011). Petambak Garam Indonesia dalam Kepungan Kebijakan dan Modal. Ininnawa, Indonesia Berdikari, INFID.

Raffles, T. S. (2014). The History of Java. Narasi.

Ricklefs, M. C. (2005). Sejarah Indonesia Modern. UGM Press.

Rifa'i, M. A. (2007). Manusia Madura: Pembawaan, Perilaku, Etos Kerja, Penampilan, dan Pandangan Hidupnya seperti Dicitrakan Peribahasanya. Pilar Media.

Rochwulaningsih, Y. (2008). Marjinalisasi Petani Garam dan Ekspansi Ekonomi Global: Kasus di Kabupaten Rembang Jawa Tengah. IPB.

Rochwulaningsih, Y. (2016). Senjata Kaum Lemah: Perlawanan Sehari-Hari Petambak Garam. Jurnal Sejarah Citra Lekha, 1(2), 121-132.

Rozaki, A. (2004). Menabur Kharisma Menuai Kuasa: Kiprah Kiai dan Blater sebagai Rezim Kembar Di Madura. Pustaka Marwa.

Sajogjo. (1993). Kata Pengantar. In Scott, J. C. Perlawanan Kaum Tani. Yayasan Pustaka Obor Indonesia.

Scott, J. C. (1981). Moral Ekonomi Petani: Pergolakan dan Subsistensi di Asia Tenggara. LP3ES.

Scott, J. C. (1986). Everyday Forms of Peasant Resistance. The Journal of Peasant Studies, $13(2), 5-34$. 
Scott, J. C. (1993). Perlawanan Kaum Tani. Yayasan Obor Indonesia.

Scott, J. C. (2000). Senjatanya Orang-orang Yang Kalah: Bentuk-bentuk Perlawanan Seharihari Kaum Tani. Yayasan Obor Indonesia.

Scott, J C. (1977). The Moral Economy of the Peasant: Rebellion and Subsistence in Southeast Asia. Yale University Press.

Scott, J C. (1985). Weapon of the Weak: Everyday Froms of Peasant Resistance. Yale University Press.

Scott, James C. (1981). Moral Ekonomi Petani. LP3ES.

Soegianto. (2003). Kepercayaan, Magi dan Tradisi Dalam Masyarakat Madura (Soegianto (Ed.)). Penerbit Tapal Kuda.

Soetarto, E. \& Shohibuddin, M. (2005). Reforma Agraria: Prasyarat Utama Bagi Revitalisasi Pertanian dan Pedesaan. Konsorsium Pembaruan Agraria.

Soetarto, E. et al. (2007). Land Reform by Leverage: Kasus Distribusi Lahan Di Jawa Timur. Sodality: Jurnal Sosiologi Pedesaan, 1(2), 271-282.

Suhelmi, I. R. et al. (2013). Garam Madura: Tradisi Dan Potensi Usaha Garam Rakyat. Badan Penelitian Dan Pengembangan Kelautan Dan Perikanan Kementerian Kelautan Dan Perikanan.

Suwito \& Muhbib. (2002). Islam Dan Hegemoni Sosial (Khaeroni (Ed.)). Media Cita.

Suwondo, B. (1982). Sistem Gotong Royong dalam Masyarakat Desa Daerah Jawa Timur. Departemen P \& K.

Syafi, I. (2013). Persaingan Pengangkutan Garam di Selat Madura. Jurnal Sejarah CITRA LEKHA, XVII(1), 85-104.

Taufiqurrahman. (2007). Identitas Budaya Madura. KARSA, XI (1), 1-11.

The CDMI Consulting Group. (2019). Studi Potensi Bisnis Dan Pelaku Utama Industri Garam Di Indonesia, 2019-2023. CDMI.

Wolf, E. (2004). Perang Petani. Insist Press.

Woodward, M. R. (2002). Islam Di Jawa. LKiS.

Yulinda, N. A., Badriyanto, B. S., \& Parwata. (2014). Konflik Lahan Pegaraman di Kecamatan Gapura Kabupaten Sumenep Tahun 1975-1985. Publika Budaya, 2(1), 6977. 